\title{
Rootstocks and Plant Water Relations Affect Sugar Accumulation of Citrus Fruit Via Osmotic Adjustment
}

\author{
Graham H. Barry ${ }^{1}$ and William S. Castle \\ Citrus Research and Education Center, University of Florida, 700 Experiment Station Road, Lake \\ Alfred, FL 33850-2299 \\ Frederick S. Davies \\ Department of Horticultural Sciences, University of Florida, P.O. Box 110690, Gainesville, \\ FL 32611-0690
}

\begin{abstract}
ADDITIONAL INDEX WORDS. Citrus sinensis, juice quality, midday stem water potential $\left(\psi_{\text {stem }}\right)$, soluble solids concentration (SSC), titratable acidity (TA), water-deficit stress
\end{abstract}

\begin{abstract}
Citrus rootstocks have well-known effects on tree size, crop load, fruit size, and various fruit quality factors. Fruit from trees budded on invigorating rootstocks are generally larger with lower soluble solids concentration (SSC) and titratable acidity compared to fruit from trees budded on less invigorating rootstocks. Although it is unclear how rootstocks exert their influence on juice quality of Citrus $\mathrm{L}$. species, plant water relations are thought to play a central role. In addition, the larger fruit size associated with invigorating rootstocks and the inverse relationship between SSC and fruit size implies that fruit borne on trees on invigorating rootstocks have lower SSC due to dilution effects in larger fruit. To determine how rootstock type affects sugar accumulation in fruit of $C$ itrus species, controlled water-deficit stress was applied to mature 'Valencia' sweet orange [C. sinensis $(\mathrm{L}$.) Osb.] trees on Carrizo citrange [C. sinensis $\times$ Poncirus trifoliata (L.) Raf.] or rough lemon (C.jambhiri Lush.) rootstocks. Withholding water from the root zone of citrus trees during stage II of fruit development decreased midday stem water potential and increased the concentrations of primary osmotica, fructose and glucose. Sucrose concentration was not affected, suggesting that sucrose hydrolysis took place. Increased concentrations of sugars and SSC in fruit from moderately water-stressed trees occurred independently of fruit size and juice content. Thus, passive dehydration of juice sacs, and concentration of soluble solids, was not the primary cause of differences in sugar accumulation. Controlled water-deficit stress caused active osmotic adjustment in fruit of 'Valencia' sweet orange. However, when water-deficit stress was applied later in fruit development (e.g., stage III) there was no increase in sugars or SSC. The evidence presented supports the hypothesis that differential sugar accumulation of citrus fruit from trees on rootstocks of contrasting vigor and, hence, plant water relations, is caused by differences in tree water status and the enhancement of sucrose hydrolysis into component hexose sugars resulting in osmotic adjustment. Therefore, inherent rootstock differences affecting plant water relations are proposed as a primary cause of differences in sugar accumulation and SSC among citrus rootstocks.
\end{abstract}

Citrus rootstocks have well-known effects on tree size, crop load, fruit size, and various fruit quality factors (Castle, 1987; Castle et al., 1993; Wutscher, 1979, 1988). The classic example of differences in fruit quality among rootstocks is represented by comparison of fruit borne on trees on rough lemon with those on sour orange (Citrus aurantium L.) rootstocks (Albrigo, 1977; Cook et al., 1952; Harding, 1947). Fruit from trees on rough lemon are generally large, and low in SSC and titratable acidity (TA) compared with fruit from trees on sour orange which produce superior quality fruit because of their high SSC, good flavor and adequate size (Castle et al., 1993).

Citrus rootstocks have been characterized according to the vigor imparted to the scion and tree productivity (Castle et al., 1993). Scions budded on invigorating rootstocks [e.g., rough lemon, Volkamer lemon (C. volkameriana Ten. \& Pasq.), and macrophylla (C. macrophylla Wester)] generally produce large

Received for publication 29 Aug. 2003. Accepted for publication 11 July 2004 Florida Agricultural Experiment Station Journal Series No. R-09522. This study was made possible by partial funding from Capespan International, South Africa, and Tropicana Products Inc., Fla. The authors acknowledge the cooperation of Lykes Bros. Inc., Fla., and Linda Barry, Jim Baldwin, and Jean Eelman for technical assistance.

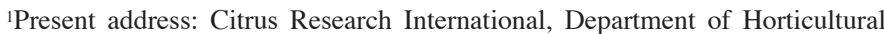
Science, Univ. of Stellenbosch, Private Bag X1, Matieland, 7602, South Africa; gbarry@sun.ac.za fruit with low SSC and TA. Trees on less invigorating rootstocks [e.g., many trifoliate orange (Poncirus trifoliata) selections and some of its hybrids such as the citranges and citrumelos $(C$. paradisi Macf. $\times$ P. trifoliata) $]$ generally produce relatively small fruit but with high SSC and TA (Castle et al., 1993; Reitz and Embleton, 1986).

Gardner (1969) used a reciprocal fruit grafting technique to explain juice quality differences of fruit from trees on different rootstocks. 'Valencia' sweet orange fruit taken from a tree on rough lemon were grafted to a tree on sour orange, and vice versa. The grafted fruit developed the size and juice quality characteristics of the rootstock on which fruit completed their growth. Gardner (1969) concluded that the tree foliage supplies carbohydrates to fruit, but the rootstock determines the amount. Although it is unclear how rootstocks exert their influence on juice quality of Citrus species, plant water relations, mineral nutrition, and phytohormones have been proposed as being among the most important factors involved (Castle, 1995). In addition, the larger fruit size associated with invigorating rootstocks together with the inverse relationship between juice SSC and TA, and fruit size (Harding and Lewis, 1941; Miller, 1990) implies that fruit borne on trees on invigorating rootstocks have lower SSC due to dilution effects in larger fruit.

Differences in juice quality of fruit from trees on different rootstocks may be related to differences in root distribution (Castle 
and Krezdorn, 1975), water or nutrient uptake efficiencies (Castle and Krezdorn, 1977), vessel element anatomy of rootstock trunk xylem (Vasconcellos and Castle, 1994), and associated differences in root hydraulic conductivity (Syvertsen and Graham, 1985). Castle (1995) hypothesized that citrus juice quality is closely related to rootstock effects on plant water relations as evidenced by results from irrigation field trials (Koo and Sites, 1955; Sites et al., 1951), sucrose transport (Koch, 1984), and reciprocal fruit grafting studies (Gardner, 1969).

Albrigo (1977) demonstrated the central role played by plant water relations to explain differences in juice quality of fruit from trees on different rootstocks. 'Valencia' sweet orange trees on rough lemon were less water-stressed (higher leaf water potential) and fruit had lower juice content and SSC than trees on sour orange or Carrizo citrange. Thus, rootstocks may influence SSC through the degree of dilution caused by the average water potential a particular rootstock maintains for the scion cultivar. The primary rootstock influence on fruit development may be by a rootstock's ability to supply water to the plant, and the secondary influence may be through nutrient uptake (Albrigo, 1992). Since invigorating rootstocks are better extractors of soil water (Castle and Krezdorn, 1977), trees on invigorating rootstocks experience less water stress than trees on less invigorating rootstocks. This may be the main reason why invigorating rootstocks produce lower SSC in individual fruit (Albrigo, 1977, 1992). If "dilution" explains why fruit from trees on rough lemon have lower SSC than fruit of similar size and juice volume from trees on Carrizo citrange, then, how does "dilution" occur?

Another role of plant water relations in explaining carbohydrate accumulation in juice sacs of Citrus is based on the observation that plants under moderate water-deficit stress accumulate more carbohydrates than unstressed plants (Meyer and Boyer, 1981; Yakushiji et al., 1996, 1998). Working with satsuma mandarin (C. unshiu Marc.), Yakushiji et al. (1996, 1998) proposed that osmotic adjustment, an increase in osmotically active solutes, occurred in citrus fruit from trees under mild water-deficit stress. Concentrations of sucrose, glucose and fructose, and absolute sugar content per fruit from moderately stressed trees were higher than in juice extracted from similar sized fruit on well-watered trees. When water potential in juice sacs decreased due to moderate water-deficit stress, turgor was maintained. Decreased osmotic potential compensated for the lower water potential. The change in osmotic potential resulted from sucrose hydrolysis that increased the concentrations of hexose sugars (osmotically active solutes) (Yakushiji et al., 1996, 1998). Because sucrose is the primary substance for translocation and phloem unloading in citrus fruit (García-Luis et al., 1991; Kriedemann, 1969; Sawamura et al., 1975), hydrolysis of sucrose to fructose and glucose must be promoted in juice sacs during the process of osmotic adjustment to maintain the osmotic gradient.

The purpose of this study was to determine how rootstock type affects sugar accumulation in fruit of Citrus species. We tested the hypothesis that controlled water-deficit stress causes active osmotic adjustment by increasing the solute concentration in fruit as sucrose is hydrolyzed to fructose and glucose.

\section{Materials and Methods}

\section{Site and plant material}

The experiment was conducted in a commercial citrus orchard near Ft. Basinger, Fla. (lat. $27^{\circ} 34^{\prime} \mathrm{N}$, long. $81^{\circ} 09^{\prime} \mathrm{W}$; elevation $14 \mathrm{~m}$ ). The soil type is Myakka fine sand (a sandy, siliceous, hyperthermic Aeric Haploquod of the Spodosol order) which is common in a flatwoods landscape position. This is a poorly drained, slightly acidic ( $\mathrm{pH} 5$ ), sandy soil with a thin organic matter layer (spodic hardpan) $\approx 12 \mathrm{~cm}$ thick and located $\approx 64 \mathrm{~cm}$ deep in the soil profile. Prior to planting, drainage ditches were installed to lower the naturally perched water table, and raised beds $\approx 1.2 \mathrm{~m}$ in height were formed to facilitate surface drainage and to increase rooting depth. Trees were planted in a double-row system, $15 \mathrm{~m}$ between bed-middles, $7.5 \mathrm{~m}$ between tree-rows on the bed, and $3.8 \mathrm{~m}$ between trees within rows, with a density of 230 trees/ha. Water was applied using a Netafim (Tel Aviv, Israel) single-line drip irrigation system with emitters spaced at $0.72 \mathrm{~m}$ intervals and an application rate of $1.2 \mathrm{~L} \cdot \mathrm{h}^{-1}$ according to crop requirement and prevailing environmental conditions recorded using a nearby automated weather station.

'Valencia' sweet orange trees on Carrizo citrange or rough lemon rootstocks planted in Mar. 1992 in a north-south row orientation were used. Trees on the two rootstocks were planted in adjacent orchards with similar site and soil conditions, and received the same cultural practices. Healthy trees with uniform crop load and tree size within each rootstock were selected.

\section{Treatments and experimental design}

The experiment was conducted over two seasons. The main factors were rootstock type (Carrizo citrange and rough lemon) and irrigation level [control, well-watered, no irrigation, and no irrigation plus ground cover (=mulch)]. There were eight trees per plot, within a row, and four replications per irrigation treatment. Irrigation treatments were assigned in a Latin square design within each rootstock.

The well-watered irrigation treatment was established by adding a second drip irrigation line to the existing line on the opposite side of tree rows resulting in double the volume of water being applied to trees at each irrigation event. For the no irrigation treatment, the drip irrigation line was replaced with polyethylene tubing without emitters. For the mulch treatment, in addition to replacing the drip irrigation line with polyethylene tubing without emitters, the entire drip-area under trees was covered with a $5.5 \mathrm{~m}$-wide water-impermeable synthetic fibrous sheet as a ground cover (Tyvek HomeWrap; Du Pont, New Castle, Del.). This material restricted surface water from entering the root zone while allowing gas exchange of water vapor and air. The control treatment was the commercial irrigation practice with a singleline drip irrigation system.

During the 1998-99 season, the irrigation treatments were applied 9 weeks prior to harvest, coinciding with stage III of fruit development, for a period of 9 weeks (i.e., 21 Jan. to 22 Mar. 1999). For the 1999-2000 season, the no irrigation treatment was excluded because no significant differences in sugar concentrations were detected between it and the mulch treatment during the previous season. In addition, because no significant differences in sugar accumulation occurred among treatments in the first season, irrigation treatments were applied 6 months prior to harvest in the 1999-2000 season, during stage II of fruit development, for a period of 19 weeks (i.e., 14 Sept. 1999 to 26 Jan. 2000).

\section{Data collection}

Before the irrigation treatments were imposed each season, and at regular intervals thereafter, stem water potential $\left(\psi_{\text {stem }}\right)$, juice quality, and reducing and nonreducing sugar concentrations of juice were measured. In the 1998-99 season, gravimetric soil water content (SWC) was determined only at harvest, whereas SWC was determined at each sampling time in the 1999-2000 
season. Data were collected from mid-Jan. through mid-Mar. 1999 and from mid-Sept. 1999 through mid-Mar. 2000.

SoIL Water Content. Composite soil samples of three adjacent cores were taken to a depth of $15 \mathrm{~cm}$ from between two trees in a row in the middle of each plot. Wet soil weight was measured immediately after sampling and dry soil weight was measured after $48 \mathrm{~h}$ at $70{ }^{\circ} \mathrm{C}$, from which the percentage soil water was determined.

Stem water potential. Based on a preliminary study to ascertain variability in $\psi_{\text {stem }}$ in 'Valencia' sweet orange trees, two leaves per tree from two trees per treatment and four replications were used to estimate $\psi_{\text {stem }}$. Mature summer- (1998-99 season) and spring-flush (1999-2000 season) terminal leaves in the sunexposed, southwest upper canopy sector at $\approx 2 \mathrm{~m}$ height were used. Intact, attached leaves were enclosed in an aluminum foilcovered black polyethylene envelope (Begg and Turner, 1970; McCutchan and Shackel, 1992; Shackel et al., 1997) beginning at $\approx 0700 \mathrm{HR}, 4$ to $5 \mathrm{~h}$ prior to measurement of midday $\psi_{\text {stem }}$. Stem water potential was measured with a pressure chamber (Scholander et al., 1965) at midday ( $\approx 1200$ to $1300 \mathrm{HR}$ ), when water potential of enclosed leaves was assumed to be in equilibrium with stem water potential.

RoOT DENSITY. Fibrous roots were sampled in three replications of each of the well-watered and mulch treatments of each rootstock at the end of the 1999-2000 season. Soil samples were taken between trees in a row and at the edge of the drip-area on the furrow side of the raised bed, at depths of 0 to $15 \mathrm{~cm}, 15$ to $30 \mathrm{~cm}$, and 30 to $60 \mathrm{~cm}$. Samples were collected using a $79 \times$ $165 \mathrm{~mm}$ auger, with a volume of $809 \mathrm{~cm}^{3}$. Soil samples were screened to recover fibrous roots with a diameter $<2 \mathrm{~mm}$, which were oven-dried for $48 \mathrm{~h}$ at $70{ }^{\circ} \mathrm{C}$ and then weighed. Fibrous root density was expressed as $\mathrm{mg} \cdot \mathrm{m}^{-3}$.

JuiCE QUALITY. A 10-fruit sample from the sun-exposed, southwest top canopy position was used for juice quality analysis. Five fruit of similar size from each of the two trees used for $\psi_{\text {stem }}$ measurements were harvested at each sampling date. Fruit equatorial diameter and fresh weight (FW) were measured. Juice was extracted using a citrus reamer (Sunkist, Sherman Oaks, Calif.) and weighed. Brix of juice samples was measured with a hand-held temperature-compensated Brix refractometer (Atago, Kirkland, Wash.), and acid content was determined by titration with $0.3125 \mathrm{~N} \mathrm{NaOH}$ and $0.5 \%$ phenolphthalein solution. The acid correction factor was added to Brix measurements to determine SSC (Fellers, 1990). Juice content of fruit samples was determined (w/w), and the ratio of SSC : TA was calculated. A $20 \mathrm{~mL}$ filtered juice sample was frozen immediately after extraction.

Sugar AnALysis. The filtered juice samples were analyzed for reducing and nonreducing sugar concentrations by high-performance liquid chromatography (Song et al., 1998). The thawed samples were shaken and a $10 \mathrm{~mL}$ aliqout was centrifuged at $6500 g_{\mathrm{n}}$ for $5 \mathrm{~min}$ at $5^{\circ} \mathrm{C}$. A $3-\mathrm{mL}$ aliqout of supernatant was filtered through a $0.8 / 0.2 \mu \mathrm{m}$ Acrodisc PF double syringe filter (Gelman Sciences, Ann Arbor, Mich.) into a 1-mL Sepcap autoinjection vial (National Scientific Co., Lawrenceville, Ga.). The sample injection volume used was $10 \mu \mathrm{L}$ using a Waters 717 plus Autosampler and Waters 600E System Controller (Millipore, Milford, Mass.), and the sugars were eluted into a Zorbax $\mathrm{NH}_{2}$ column $(4.6 \mathrm{~mm} \times 25 \mathrm{~cm})$ isocratically with a mobile phase of $75 \%$ acetonitrile-water $(\mathrm{v} / \mathrm{v})$ at a flow rate of $1.5 \mathrm{~mL} \cdot \mathrm{min}^{-1}$ and operating temperature of $10{ }^{\circ} \mathrm{C}$. The eluate was monitored by an HP 1037A refractive index detector (Hewlett Packard, Palo Alto, Calif.), and data were integrated using Millennium chro- matography manager software (Millipore, Milford, Mass.). The concentrations of fructose, glucose, and sucrose were calculated based on previously run standard solutions. Sugar concentrations were reported as $\mathrm{g} / 100 \mathrm{~mL}$ juice.

In the 1999-2000 season, juice sugars were analyzed in samples from only the two extreme irrigation level treatments, well-watered and mulch treatments.

Juice OSMOTIC POTENTIAL. The osmotic potential $\left(\psi_{s}\right)$ of juice samples used for sugar analysis from the 1999-2000 season was measured using a Model $5100 \mathrm{~B}$ vapor pressure osmometer (Wescor, Logan, Utah) calibrated with $\mathrm{NaCl}$ standards.

\section{Statistical analysis}

Conducting the research in a commercial orchard imposed a limitation on the experimental design as rootstock treatments could not be randomly allocated to blocks. Therefore, juice quality, sugar concentration, $\psi_{s}, \psi_{\text {stem }}$, SWC, and fibrous root density data were initially analyzed separately for each rootstock as two randomized complete block designs using PROC GLM and the appropriate error term for each treatment effect (SAS Institute Inc., 1996). The results of those analyses, and other information related to site and soil uniformity, suggested that the two sites were similar enough for the data also to be combined and re-analyzed as a split-plot design to make comparisons between rootstocks. In this case, rootstock represented the whole-plot unit and irrigation treatment the sub-plot unit. Means were separated by least significant difference (LSD).

\section{Results}

\section{8-99 season}

At the end of the first season of study (22 Mar. 1999), mean SWC of the control treatment for both Carrizo citrange and rough lemon was $7.6 \%$. There was no significant difference in SWC between the control and well-watered treatments. Where irrigation water was withheld from trees for 9 weeks, SWC of the mulched Carrizo citrange treatment $(\approx 5 \% \mathrm{SWC})$ and both rough lemon treatments that did not receive water $(\approx 3 \% \mathrm{SWC})$ were significantly lower than the control and well-watered treatments. Soil water content of the Carrizo citrange no irrigation treatment was intermediate ( $\approx 6 \%$ SWC). Field capacity (FC) of Myakka fine sand is $\approx 13 \%$ SWC (Sodek et al., 1990). Therefore, the wellwatered and control treatments were at $\approx 40 \%$ soil water depletion, whereas the Carrizo citrange no irrigation and mulch treatments were at $\approx 55 \%$ and $60 \%$ soil water depletion, respectively. Both rough lemon treatments that received no irrigation were at $\approx 75 \%$ soil water depletion.

Stem water potential did not differ among irrigation treatments within each rootstock at the start of the experiment on 21 Jan. 1999 (Fig. 1). However, $\psi_{\text {stem }}$ was significantly lower for trees on Carrizo citrange $(-0.86 \mathrm{MPa})$ than rough lemon $(-0.64 \mathrm{MPa})$. Within 3 weeks, by 12 Feb. 1999, trees in the mulched Carrizo citrange treatment had significantly lower $\psi_{\text {stem }}$ than the other Carrizo citrange treatments. For the remainder of the experiment, there was little change in $\psi_{\text {stem }}$ among irrigation treatments. When the experiment was terminated on 22 Mar. 1999, $\psi_{\text {stem }}$ of trees in the mulched Carrizo citrange treatment were significantly lower than those of the other Carrizo citrange treatments, being $\approx 0.2$ MPa lower for the mulch treatment than the control. Trees on rough lemon that received no irrigation and were mulched had $\approx 0.15 \mathrm{MPa}$ lower $\psi_{\text {stem }}$ than trees receiving normal (control) and extra irrigation. 
On all sampling dates, there were no differences in SSC among irrigation treatments within a rootstock (data not shown), but SSC was significantly higher for fruit from trees on Carrizo citrange rootstock than rough lemon rootstock. At final harvest (22 Mar. 2001), fruit samples from trees on Carrizo citrange had $\approx 13 \%$ SSC compared to $<10 \%$ SSC for fruit from trees on rough lemon. Reducing and nonreducing sugar concentrations at maturity were also unaffected by irrigation treatment, but reducing and nonreducing sugar concentrations were significantly higher for fruit from trees on Carrizo citrange than rough lemon (data not shown).

\section{9-2000 season}

SoIL WATER CONTENT. Mean SWC at the start of the irrigation treatments on 14 Sept. 1999 was $\approx 12.5 \%$ with no statistical difference among treatments and between rootstocks (Fig. 2). SWC decreased for all treatments from 14 Sept. 1999 through 5 Nov. 1999, and then increased for the control and well-watered treatments, following irrigation and rain. However, SWC for the mulch treatment became progressively lower through the duration of the experiment. On 26 Jan. 2000, SWC of the mulch treatment was significantly lower than the other treatments (5.5\% and 5.0\% for soil from Carrizo citrange and rough lemon plots, respectively; $\approx 60 \%$ soil water depletion).

Stem Water Potential. At each time of measurement, $\psi_{\text {stem }}$ of 'Valencia' sweet orange trees on Carrizo citrange was significantly lower than $\psi_{\text {stem }}$ of trees on rough lemon (Fig. 3 ). When irrigation treatments were imposed on 14 Sept. 1999, available soil water was close to FC (Fig. 2), and mean $\psi_{\text {stem }}$ of trees on Carrizo citrange was $-1.08 \mathrm{MPa}$, compared with -0.53 MPa for trees on rough lemon (Fig. 3). Eight weeks later, on 5 Nov. 1999, $\psi_{\text {stem }}$ of trees on Carrizo citrange had decreased by at least 0.3 $\mathrm{MPa}$, the largest decrease was for the mulch treatment $(\approx 0.55 \mathrm{MPa})$ with a difference of $\approx 0.4$ $\mathrm{MPa}$ between the control and mulch treatments on that date. Twelve weeks after imposing the irrigation treatments (10 Dec. 1999), $\psi_{\text {stem }}$ of trees on Carrizo citrange had increased, with a difference in $\psi_{\text {stem }}$ of $\approx 0.3 \mathrm{MPa}$ between the well-watered and mulch treatments. The $\psi_{\text {stem }}$ of the control treatment was intermediate, but significantly higher than the mulch treatment at this time. Trees on rough lemon followed a similar pattern. However, the response of $\psi_{\text {stem }}$ to irrigation treatment was not manifested until 10 Dec. 1999 and the difference between treatments $(0.2 \mathrm{MPa})$ was smaller than for trees on Carrizo citrange. The small increase in $\psi_{\text {stem }}$ of trees on rough lemon between 5 Nov. and 10 Dec. 1999 is a reflection of the increase in SWC over the same period (Fig. 2), and is probably a residual effect of Hurricane Irene (16 Oct. 1999), when $300 \mathrm{~mm}$ rain fell in $3 \mathrm{~d}$.

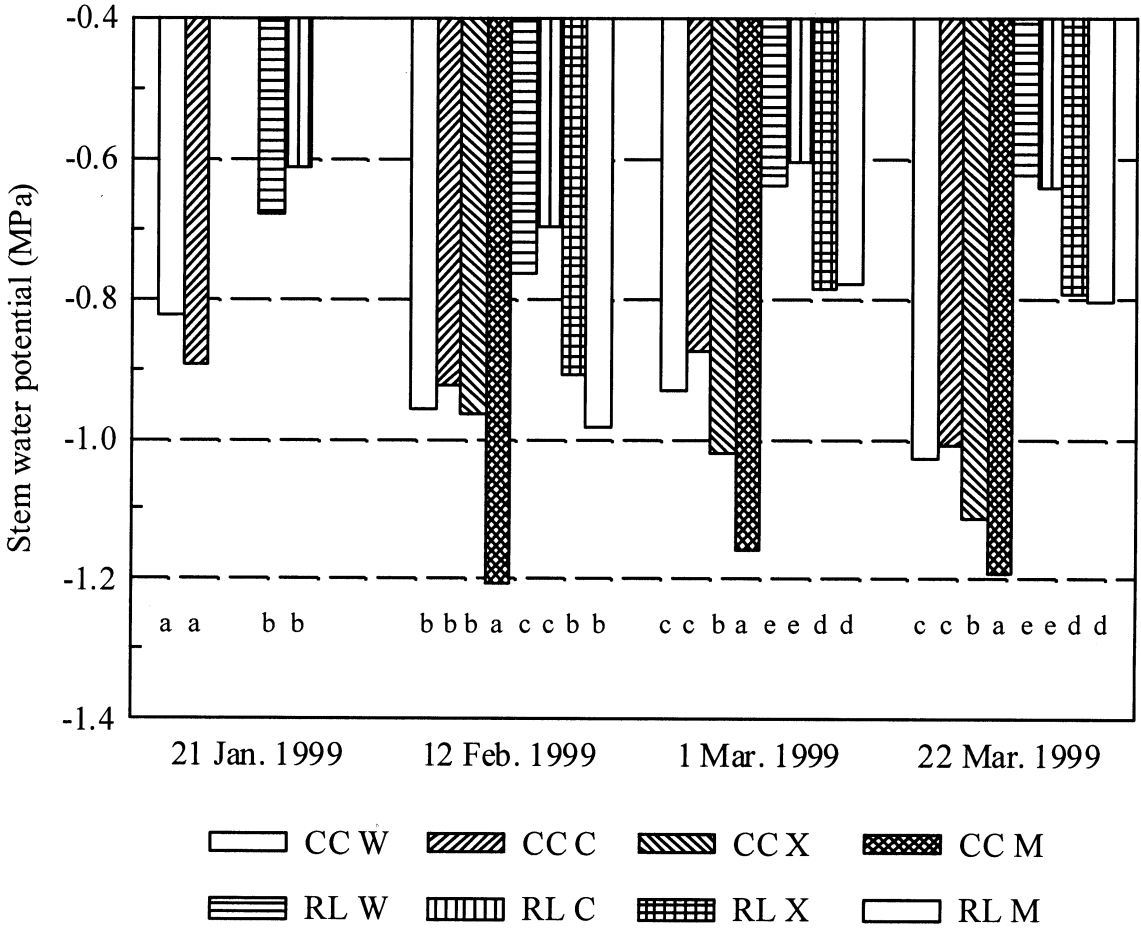

Fig. 1. Midday stem water potential of 'Valencia' sweet orange trees on Carrizo citrange (CC) and rough lemon (RL) rootstocks at four irrigation levels ( $\mathrm{W}=$ well-watered, $\mathrm{C}=$ control, $\mathrm{X}=$ no irrigation, and $\mathrm{M}=$ no irrigation plus mulch) during stage III of fruit development in the 1998-99 season. Bars with the same letter, within a date, are not significantly different $(P \leq 0.05 ; 21$ Jan.1999: $\mathrm{n}=4$ trees, number of leaves $=4$; all other dates: $n=4$ replications, no. of trees $=2$, no. of leaves $=2$ )

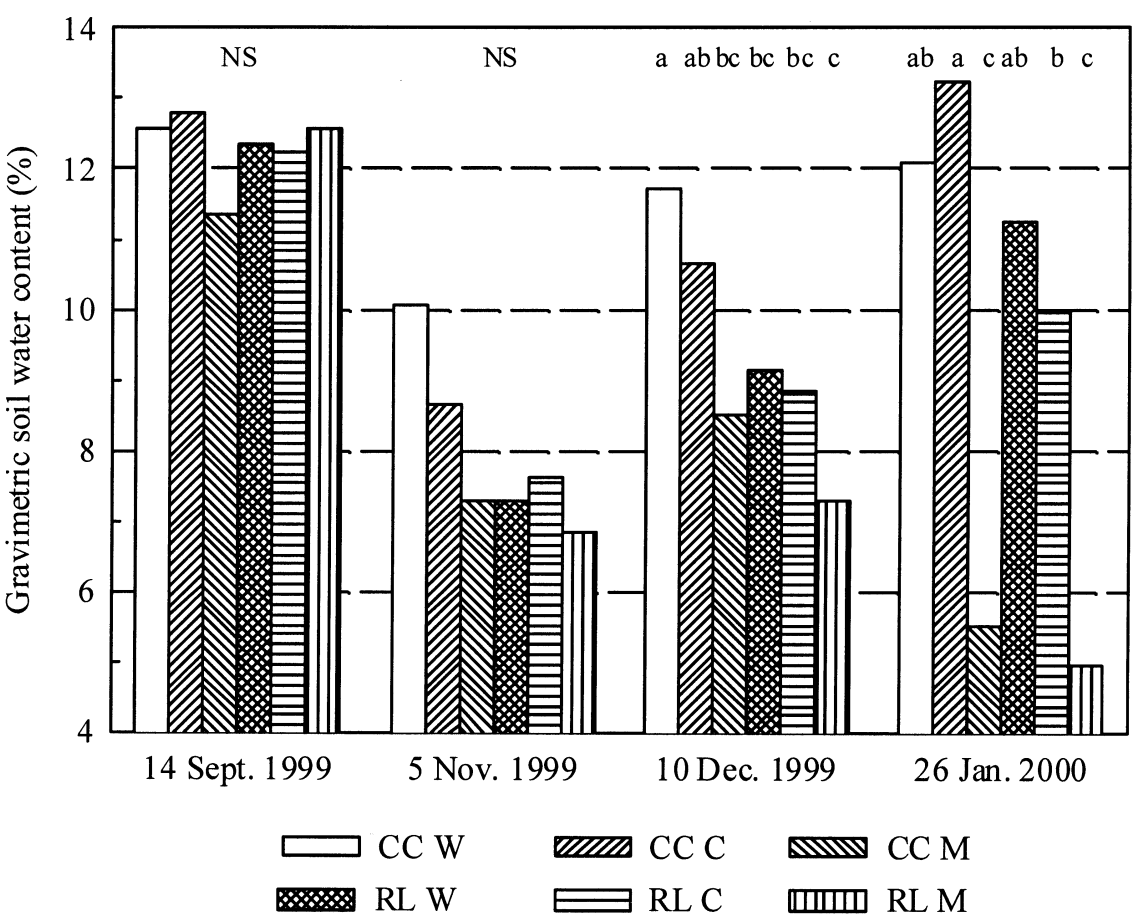

Fig. 2. Gravimetric soil water content of soil samples taken from the drip-area between two trees of 'Valencia' sweet orange trees on Carrizo citrange (CC) and rough lemon (RL) rootstocks at three irrigation levels ( $\mathrm{W}=$ well-watered, $\mathrm{C}=$ control, and $\mathrm{M}=$ no irrigation plus mulch) during stages II and III of fruit development in the 1999-2000 season. Bars with the same letter, within a date, are not significantly different $(P \leq 0.05$, NS $=$ nonsignificant; $\mathrm{n}=4$, eight-tree plots $)$. 


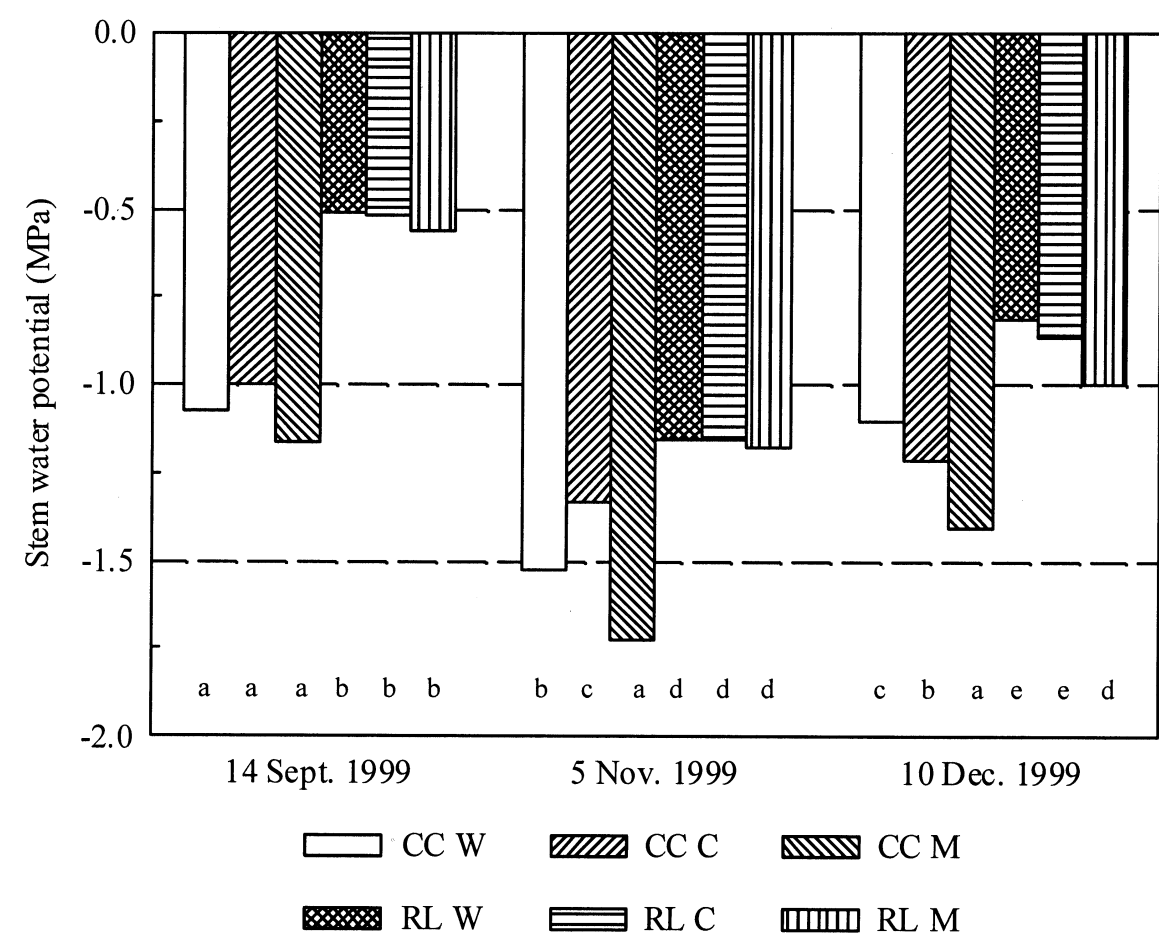

Fig. 3. Midday stem water potential of 'Valencia' sweet orange trees on Carrizo citrange (CC) and rough lemon (RL) rootstocks at three irrigation levels $(\mathrm{W}=$ well-watered, $\mathrm{C}=$ control, and $\mathrm{M}=$ no irrigation plus mulch) during stages II and III of fruit development in the 1999-2000 season. Bars with the same letter, within a date, are not significantly different $(P \leq 0.05 ; \mathrm{n}=4$ replications, number of trees $=2$, number of leaves $=2$ ).

Root DENSITY. Fibrous root density of Carrizo citrange was $<50 \%$ that of rough lemon $\left(350 \mathrm{mg} \cdot \mathrm{m}^{-3} \mathrm{vs} .800 \mathrm{mg} \cdot \mathrm{m}^{-3}\right)$, and there was no difference in fibrous root density between the well-watered and mulch irrigation treatments for Carrizo citrange. For rough lemon, fibrous root density of the well-watered treatment was nearly double that of trees in the mulch treatment $\left(990 \mathrm{mg} \cdot \mathrm{m}^{-3}\right.$ vs. $\left.580 \mathrm{mg} \cdot \mathrm{m}^{-3}\right)$. For both rootstocks, the majority $(\approx 80 \%)$ of fibrous roots were in the top $15 \mathrm{~cm}$ of the soil, with little or no root penetration through the organic layer or light gray sandy B horizon.

Fruit SIZE AND JUICE QUaLITY. At the start of the experiment (14 Sept. 1999), there were no significant differences in FW, juice content, SSC, TA, and reducing and nonreducing sugar concentrations among irrigation treatments (Table 1; Figs. 4 and $5)$. At this time, fruit were in stage II of their development $(\approx 170$ $\mathrm{g} \mathrm{FW}$ and $69 \mathrm{~mm}$ equatorial fruit diameter). However, rootstock differences were already manifested for juice content and SSC as the values were greater for fruit from trees on Carrizo citrange than from trees on rough lemon. This rootstock effect was maintained through maturity (Figs. 4 and 5). At maturity (15 Mar. 2000), fruit from trees on Carrizo citrange were smaller (236 g $\mathrm{FW}, 75 \mathrm{~mm}$ diameter) than fruit from trees on rough lemon (272 g FW, $80 \mathrm{~mm}$ diameter), with higher juice content (55.8\% vs. $53.3 \%)$, SSC ( $12.8 \%$ vs. $10.3 \%)$, TA ( $0.87 \%$ vs. $0.75 \%)$ (Table 2 ), and ratio (14.8:1 vs. 13.7:1). For all juice quality variables at all sampling dates, except for FW, and fructose and glucose concentrations on 26 Jan. 2000 , the rootstock $\times$ irrigation interaction was nonsignificant.

Within each rootstock, FW was unaffected by irrigation treatment until 10 Dec. 1999 (Fig. 4A). At this stage, fruit from the Carrizo citrange well-watered treatment were significantly heavier than fruit from the control and mulch treatments, and fruit from the rough lemon well-watered and control treatments were significantly heavier than fruit from the mulch treatment. On 26 Jan. 2000 there was an inconsistent response of FW to irrigation treatment for the two rootstocks (significant rootstock $\times$ irrigation interaction); fruit from trees on Carrizo citrange subjected to the well-watered treatment were significantly heavier than fruit from the control and mulch treatments (similar to 10 Dec. 1999), whereas fruit from trees on rough lemon subjected to the well-watered and mulch treatments were significantly heavier than fruit from the control treatment. The smaller size of fruit from the rough lemon control treatment may have been due to sampling error as the amount of fruit available for sampling was limited at that sampling time. At maturity, however, there was no significant difference in FW among irrigation treatments within each rootstock (Table 2; Fig. 4A).

At each sampling date, there was no significant difference in juice content among irrigation treatments within rootstock, except on 26 Jan. 2000 for fruit from the rough lemon control treatment (Fig. 4B). The higher juice content measured may have been due to the smaller size of fruit sampled for that treatment.

On 5 Nov. 1999, there was no significant difference in SSC among irrigation treatments within rootstocks, although it appeared that SSC of fruit from the no irrigation plus mulch treatment for both rootstocks was starting to diverge from the other treatments (Fig. 4C). Twelve weeks after applying the irrigation treatments (10 Dec. 1999), differences in juice soluble solids accumulation among irrigation treatments were first observed. Trees on Carrizo citrange tended to produce fruit of higher SSC $(P=0.1384)$ for the mulch and control treatments compared with the well-watered treatment, and fruit from trees on the mulched rough lemon treatment also tended to produce higher SSC $(P=0.1157)$ compared with the well-watered treatment (Fig. 4C). By 26 Jan. 2000, fruit from the well-watered trees on Carrizo citrange bore fruit of significantly lower SSC $(10.9 \%$ SSC) than control and mulch treatments $(11.5 \%$ SSC $)(P$ $=0.0569$; Fig. $4 \mathrm{C})$. There was no significant difference in SSC among treatments for fruit from trees on rough lemon at this date, although fruit from the mulch treatment tended to have higher SSC (9.7\% SSC) than fruit from the well-watered treatment (9.4\% SSC). At maturity, fruit from trees on the mulched Carrizo citrange treatment produced fruit with significantly higher SSC than trees subjected to the well-watered treatment (13.0\% vs. 12.4\% SSC) (Fig. 4C). A similar response occurred for the same irrigation treatments with rough lemon (10.8\% vs. $9.7 \%$ SSC). Juice SSC of fruit from trees receiving the control treatment was not significantly different from the mulch treatment, but tended to be numerically lower than the mulch treatment.

Sugar accumulation. Eight weeks after the start of the irrigation treatments (5 Nov. 1999), there were significant differences in fructose and glucose concentrations between irrigation treatments for fruit from trees on Carrizo citrange $(P<0.04$; Fig. 5 A and B), but not on 10 Dec. 1999. On 26 Jan. and 15 Mar. 2000, 
Table 1. Means ( $n=3$, eight-tree plots) and probability values of juice quality and sugar composition of 'Valencia' sweet oranges for rootstock and irrigation treatments at the start of the experiment on 14 Sept. 1999 at Ft. Basinger, Fla.

\begin{tabular}{|c|c|c|c|c|c|c|c|c|}
\hline \multirow{2}{*}{$\begin{array}{l}\text { Source of } \\
\text { variation }\end{array}$} & \multirow[b]{2}{*}{$\mathrm{FW}^{\mathrm{z}}(\mathrm{g})$} & \multicolumn{2}{|l|}{ Juice } & \multirow[b]{2}{*}{$\mathrm{TA}^{\mathrm{w}}(\%)$} & \multicolumn{4}{|c|}{ Sugar concn (g/100 mL juice) } \\
\hline & & cont. ${ }^{y}(\%)$ & $\operatorname{SSC}^{x}(\%)$ & & Fructose & Glucose & Sucrose & Total sugars \\
\hline \multicolumn{9}{|l|}{ Rootstock } \\
\hline Carrizo citrange & 170.5 & 46.6 & 7.9 & 1.91 & 1.58 & 1.55 & 2.26 & 5.39 \\
\hline Rough lemon & 169.8 & 43.4 & 7.1 & 2.10 & 1.36 & 1.32 & 1.87 & 4.55 \\
\hline$P$ & 0.9101 & 0.0486 & 0.0001 & 0.5281 & 0.2392 & 0.2248 & 0.1866 & 0.2046 \\
\hline \multicolumn{9}{|l|}{ Irrigation } \\
\hline Well-watered & 171.9 & 45.2 & 7.4 & 1.94 & 1.51 & 1.46 & 2.15 & 5.12 \\
\hline Control & 167.5 & 45.7 & 7.5 & 1.98 & --- & --- & --- & --- \\
\hline Mulch & 171.2 & 44.1 & 7.5 & 2.10 & 1.43 & 1.41 & 1.99 & 4.83 \\
\hline$P$ values & 0.8145 & 0.6597 & 0.5281 & 0.4770 & 0.6619 & 0.7636 & 0.5602 & 0.6384 \\
\hline
\end{tabular}

${ }^{\mathrm{z} F r u i t}$ fresh weight.

y Juice content (w/w).

xSoluble solids concentration.

wTitratable acidity.

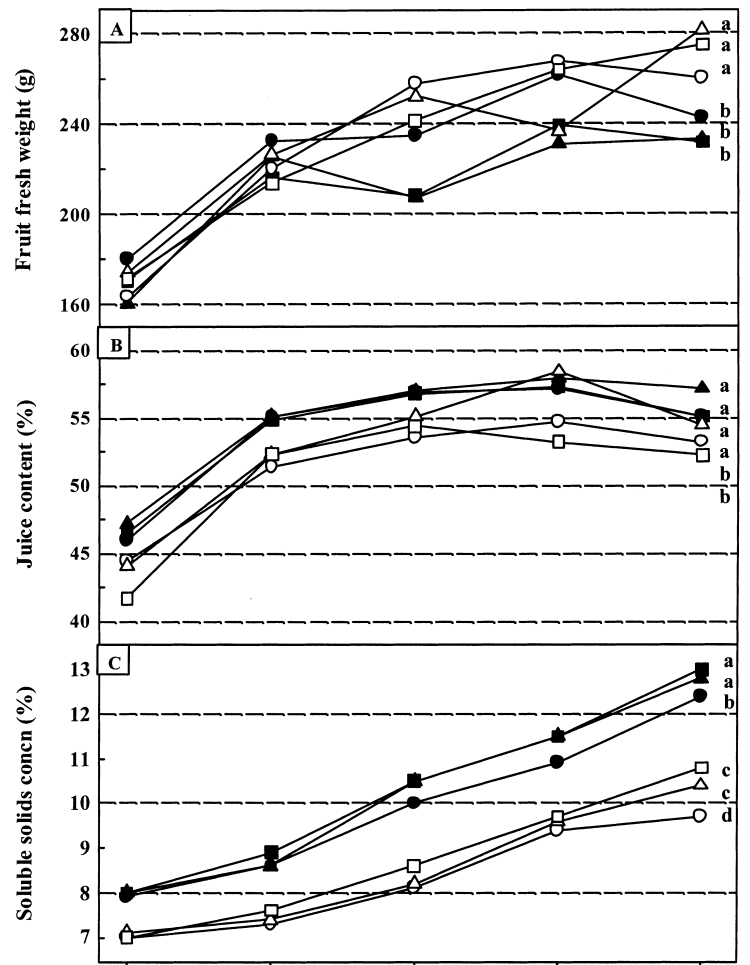

14 Sept. 19995 Nov. $1999 \quad 10$ Dec. $1999 \quad 26$ Jan. $2000 \quad 15$ Mar. 2000

$\rightarrow \mathrm{CCW} \backsim-\mathrm{CCC} \rightarrow-\mathrm{CCM} \multimap-\mathrm{RLW} \leadsto-\mathrm{RLC} \rightarrow \square-\mathrm{RLM}$

Fig. 4. Seasonal changes in (A) fruit fresh weight, (B) juice content, and (C) soluble solids concentration of 'Valencia' sweet oranges on Carrizo citrange (CC) and rough lemon (RL) rootstocks at three irrigation levels $(\mathrm{W}=$ wellwatered, $\mathrm{C}=$ control, and $\mathrm{M}=$ no irrigation plus mulch) during stages II and III of fruit development in the 1999-2000 season. Means with the same letter are not significantly different $(P \leq 0.05$, NS $=$ nonsignificant; $\mathrm{n}=3$, eight-tree plots; significant differences shown for last sample date only).

fructose and glucose concentrations were significantly higher for juice from fruit borne on trees in the mulch treatment, but there was no significant difference in sucrose concentration due to water-deficit stress (Fig. 5C).

No treatment differences in juice reducing and nonreducing sugars were observed among fruit from trees on rough lemon until 15 Mar. 2000. Fructose and glucose concentrations were significantly higher on that date for fruit from the mulch treatment compared with the well-watered treatment. There was no

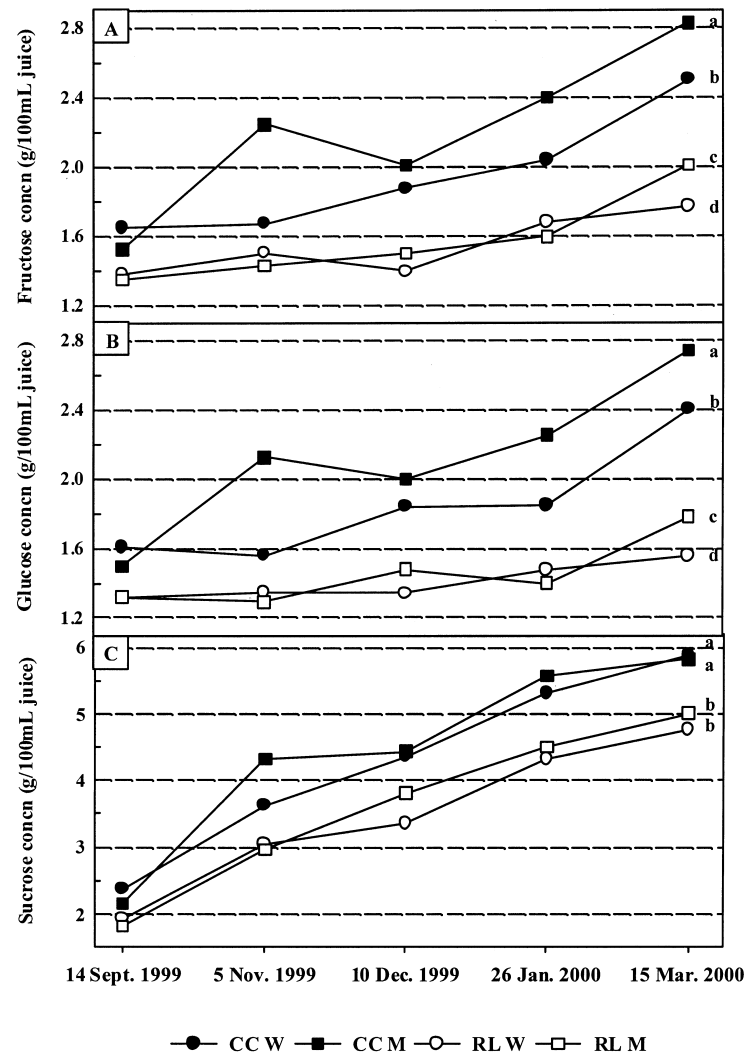

Fig. 5. Seasonal changes in (A) fructose, $(\mathbf{B})$ glucose, and $(\mathbf{C})$ sucrose concentrations of 'Valencia' sweet oranges on Carrizo citrange (CC) and rough lemon (RL) rootstocks at two irrigation levels $(\mathrm{W}=$ well-watered and $\mathrm{M}=$ no irrigation plus mulch) during stages II and III of fruit development in the 1999-2000 season. Means with the same letter are not significantly different $(P \leq 0.05$; NS = nonsignificant; $\mathrm{n}=3$, eight-tree plots; significant differences shown for last sample date only).

significant difference in sucrose concentration for fruit from the two irrigation treatments (Fig. 5).

JUiCE OSMOTIC POTENTIAL. At each sampling time, juice $\psi_{s}$ was significantly lower in fruit from trees on Carrizo citrange than rough lemon (Fig. 6). For both rootstocks, $\psi_{s}$ was significantly lower in juice samples from the mulch compared with the wellwatered treatment, except on 14 Sept. 1999 and for rough lemon on 26 Jan. 2000. 
Table 2. Means ( $\mathrm{n}=3$, eight-tree plots) and probability values of juice quality and sugar composition of 'Valencia' sweet oranges for rootstock and irrigation treatments at the end of the experiment on 15 Mar. 2000 at Ft. Basinger, Fla.

\begin{tabular}{|c|c|c|c|c|c|c|c|c|}
\hline \multirow{2}{*}{$\begin{array}{l}\text { Source of } \\
\text { variation }\end{array}$} & \multirow[b]{2}{*}{$\mathrm{FW}^{\mathrm{z}}(\mathrm{g})$} & \multicolumn{2}{|l|}{ Juice } & \multirow[b]{2}{*}{$\mathrm{TA}^{\mathrm{w}}(\%)$} & \multicolumn{4}{|c|}{ Sugar concn $(\mathrm{g} / 100 \mathrm{~mL}$ juice $)$} \\
\hline & & cont. ${ }^{y}(\%)$ & $\operatorname{SSC}^{x}(\%)$ & & Fructose & Glucose & Sucrose & Total sugars \\
\hline \multicolumn{9}{|l|}{ Rootstock } \\
\hline Carrizo citrange & 235.6 & 55.8 & 12.8 & 0.87 & 2.66 & 2.56 & 5.91 & 11.13 \\
\hline Rough lemon & 271.9 & 53.3 & 10.3 & 0.75 & 1.85 & 1.62 & 4.76 & 8.23 \\
\hline$P$ & 0.0017 & 0.0091 & 0.0001 & 0.0052 & 0.0001 & 0.0001 & 0.0017 & 0.0001 \\
\hline \multicolumn{9}{|l|}{ Irrigation } \\
\hline Well-watered & 251.1 & 54.1 & 11.0 & 0.79 & 2.09 & 1.93 & 5.23 & 9.26 \\
\hline Control & 257.2 & 55.8 & 11.6 & 0.80 & --- & --- & --- & --- \\
\hline Mulch & 253.0 & 53.7 & 11.9 & 0.84 & 2.41 & 2.25 & 5.44 & 10.09 \\
\hline$P$ values & 0.8421 & 0.1010 & 0.0011 & 0.3672 & 0.0106 & 0.0081 & 0.3755 & 0.0414 \\
\hline
\end{tabular}

Fruit fresh weight.

yJuice content $(\mathrm{w} / \mathrm{w})$.

xSoluble solids concentration.

w Titratable acidity.

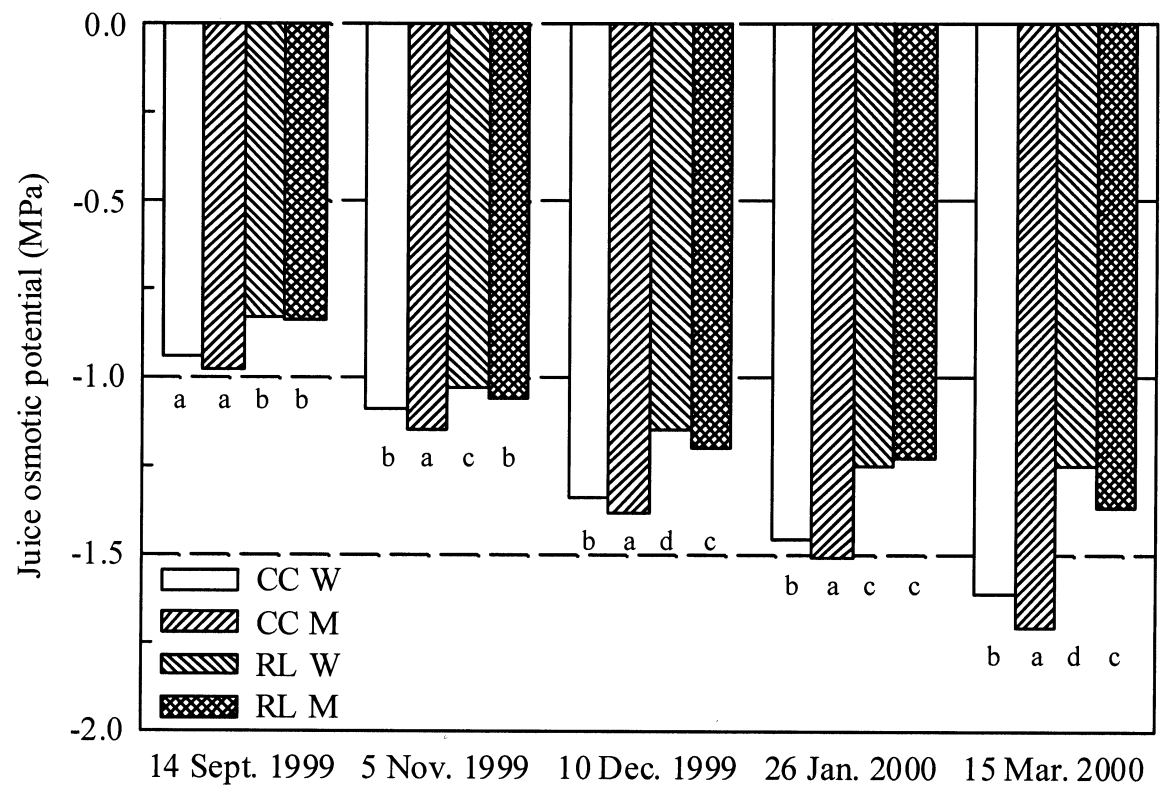

Fig. 6. Osmotic potential of juice of 'Valencia' sweet oranges on Carrizo citrange (CC) and rough lemon (RL) rootstocks at two irrigation levels (W = well-watered and $\mathrm{M}=$ no irrigation plus mulch) during stages II and III of fruit development in the 1999-2000 season. Bars with the same letter, within a date, are not significantly different $(P \leq 0.05 ; \mathrm{n}=3$, eight-tree plots).

\section{Discussion}

Evidence is presented to support the hypothesis that controlled water-deficit stress caused active accumulation of solutes in fruit of 'Valencia' sweet orange by osmotic adjustment. This mechanism provides a possible explanation of how rootstock affects juice SSC in fruit of Citrus species.

Withholding water from the root zone of citrus trees during stage II of fruit development decreased $\psi_{\text {stem }}$ and increased the concentrations of primary osmotica, fructose and glucose, without affecting sucrose concentration. This resulted in fruit with higher concentrations of sugars and soluble solids. The increased concentration of hexose sugars and no difference in sucrose concentration in juice cells of fruit of mulch vs. well-watered irrigation treatments suggest that sucrose hydrolysis took place (Hockema and Etxeberria, 2001; Koch and Avigne, 1990; Lowell et al., 1989; Yakushiji et al., 1996, 1998).

These data support the proposal that sugar accumulation in satsuma mandarin fruit from moderately water-stressed trees was caused by increased osmotic potential and sucrose hydrolysis, which developed an osmotic gradient in favor of increased sucrose translocation to juice cells in fruit. This increased photosynthate partitioning to fruit, in spite of a presumed decrease in photosynthesis, was possibly a response to increased sink strength (Hockema and Etxeberria, 2001; Yakushiji et al., 1996, 1998).

Increased concentrations of sugars and soluble solids in fruit from moderately water-stressed trees occurred independently of fruit size and juice content. Therefore, passive dehydration of juice sacs, and concentration of soluble solids, were not the primary cause of differences in sugar accumulation among irrigation treatments. These data are supported by Yakushiji et al. (1996, 1998) who demonstrated that the greater sugar accumulation in satsuma mandarin fruit was not caused by passive dehydration under water-deficit stress, as both fruit sugar content and concentration, and juice content from moderately water-stressed trees were greater than in fruit from nonstressed trees (Sugai and Torikata, 1976). More recently, Hockema and Etxeberria (2001) demonstrated the involvement of sucrose hydrolyzing enzymes in this physiological process. 
Water-deficit stress had the same effect on sugar accumulation on both rootstocks, but the response manifested itself later for trees on rough lemon. The sites planted to each rootstock had similar SWC, but the trees on rough lemon were under less water stress, $\approx 35 \%$ higher $\psi_{\text {stem }}$, than those on Carrizo citrange. Similar rootstock characteristics have previously been reported for leaf water potential (Albrigo, 1977; Castle and Krezdorn, 1977; Syvertsen and Albrigo, 1980). These differences in plant water status are partly due to greater root distribution of rough lemon (Castle and Krezdorn, 1975; Menocal-Barberena, 1999). Fibrous root density data demonstrated that the rough lemon root system was more extensive than that of Carrizo citrange, allowing rough lemon to acquire water from a larger soil volume. The difference in plant water status between rootstocks implied that the root system of rough lemon was more effective at water uptake due to greater root density (Castle and Krezdorn, 1977) and greater hydraulic conductivity (Syvertsen and Graham, 1985). Rough lemon appears to have the ability to tolerate moderate waterstress, whereas Carrizo citrange is more sensitive to changes in soil water content than rough lemon.

Independent of fruit size and irrigation treatment, rootstock had a large effect on sugar accumulation and juice SSC. Fruit from trees on Carrizo citrange had $\approx 30 \%$ higher SSC at maturity than fruit from trees on rough lemon, and sugar accumulation and SSC was already greater in fruit from trees on Carrizo citrange than rough lemon by September (about mid-stage II of fruit development). The effect of rootstock on SSC was consistent with previous research (Albrigo, 1977; Castle et al., 1993).

The timing and severity of water-deficit stress appears to be important to enhancing juice quality in citrus. When applied apparently too late in fruit development (e.g., stage III) an increase in sugars and SSC was not achieved. When the water-deficit stress was imposed during stage II of fruit development, the major sugar accumulation period (Bain, 1958; Barry et al., 2001), increased sugar accumulation and SSC occurred. However, this result should be viewed with caution as it is based on only one season's data. The severity of water-deficit stress imposed, based on the difference in midday stem water potential between well-watered or control and mulch treatments, was $0.15 \mathrm{MPa}$ for rough lemon and 0.20 MPa for Carrizo citrange. These differences in stem water potential were apparently sufficient to cause differences in juice quality.

Therefore, inherent rootstock differences affecting plant water relations is proposed as a primary cause of differences in juice quality among citrus rootstocks. These differences include root distribution (Bevington and Castle, 1982; Castle and Krezdorn, 1975), water uptake ability (Castle and Krezdorn, 1977), hydraulic conductivity (Syvertsen and Graham, 1985), and leaf or stem water potentials (Albrigo, 1977; Castle and Krezdorn, 1977; Syvertsen and Albrigo, 1980). Differential sugar accumulation of citrus fruit from trees on rootstocks of contrasting vigor and, hence, plant water relations, may be caused by differences in tree water status and the enhancement of sucrose hydrolysis into component hexose sugars resulting in osmotic adjustment.

\section{Literature Cited}

Albrigo, L.G. 1977. Rootstocks affect 'Valencia' orange fruit quality and water balance. Proc. Intl. Soc. Citricult. 1:62-65.

Albrigo,L.G. 1992. Environmental influences on citrus fruit development. Proc. Second Intl. Seminar Citrus Physiol., p. 91-101. In: J.J. Ferguson and W.F. Wardowski (eds.). Factors affecting fruit quality. Citrus Short Course Proc., Fruit Crops Dept., Univ. of Fla., Gainesville, Fla.

Bain, J.M. 1958. Morphology, anatomical, and physiological changes in the developing fruit of the Valencia orange, Citrus sinensis (L.) Osbeck. Austral. J. Bot. 6:1-28.

Barry, G.H., W.S. Castle, and F.S. Davies. 2000. Juice quality of 'Valencia' sweet orange among citrus-producing regions in Florida and between canopy positions. Proc. Intl. Soc. Citricult. 1:308-314.

Begg, J.E. and N.C. Turner. 1970. Water potential gradients in field tobacco. Plant Physiol. 46:343-346.

Bevington, K.B. and W.S. Castle. 1982. Development of the root system of young 'Valencia' orange trees on rough lemon and Carrizo citrange rootstocks. Proc. Fla. State Hort. Soc. 95:33-37.

Castle, W.S. 1987. Citrus rootstocks, p. 361-399. In: R.C. Rom and R.F. Carlson (eds.). Rootstocks for fruit crops. Wiley, New York.

Castle, W.S. 1995. Rootstock as a fruit quality factor in citrus and deciduous fruit crops. N.Z. J. Crop Hort. Sci. 23:383-394.

Castle, W.S. and A.H. Krezdorn. 1975. Effect of citrus rootstocks on root distribution and leaf mineral content of 'Orlando' tangelo tree. J. Amer. Soc. Hort. Sci. 100:1-4.

Castle, W.S. and A.H. Krezdorn. 1977. Soil water use and apparent root efficiencies of citrus trees on four rootstocks. J. Amer. Soc. Hort. Sci. 102:403-406.

Castle, W.S., D.P.H. Tucker, A.H. Krezdorn, and C.O. Youtsey. 1993. Rootstocks for Florida citrus, $2^{\text {nd }}$ ed. Univ. of Fla. Coop. Ext. Serv. Publ. SP-42.

Cook, J.A., G.E. Horanic, and F.E. Gardner. 1952. Citrus rootstock trials. Proc. Fla. State Hort. Soc. 65:69-77.

Fellers, P.J. 1990. Florida's citrus juice standards for grades and their differences from United States standards for grades and United States Food and Drug Administration standards of identity. Proc. Fla. State Hort. Soc. 103:260-265.

García-Luis, A., F. Didehvar, J.L. Guardiola, and D.A. Baker. 1991. The transport of sugars in developing fruits of Satsuma mandarin. Ann. Bot. 68:349-357.

Gardner, F.E. 1969. A study of rootstock influence on citrus fruit quality by fruit grafting. Proc. First Intl. Citrus Symp. 1:359-364.

Harding, P.L. 1947. Quality in citrus fruits: Seasonal changes in relation to consumer acceptance of oranges, grapefruit, Temple oranges, and tangerines. Proc. Amer. Soc. Hort. Sci. 49:107-115.

Harding, P.L. and W.E. Lewis. 1941. The relation of size of fruit to solids, acid, and volume of juice in the principal varieties of Florida oranges. Proc. Fla. State Hort Soc. 54:52-56.

Hockema, B.R. and E. Etxeberria. 2001. Metabolic contributors to drought-enhanced accumulation of sugars and acids in oranges. J. Amer. Soc. Hort. Sci. 126:599-605.

Koch, K.E. 1984. Translocation of photosynthetic products from source leaves to aligned juice segments in citrus fruit. HortScience 19:260-261.

Koch, K.E. and W.T. Avigne. 1990. Postphloem, nonvascular transfer in citrus: Kinetics, metabolism, and sugar gradients. Plant Physiol. 93:1405-1416.

Koo, R.C.J. and J.W. Sites. 1955. Results of research and response of citrus to supplemental irrigation. Soil Sci. Soc. Fla. Proc. 15:180-190.

Kriedemann, P.E. 1969. ${ }^{14} \mathrm{C}$ translocation in orange plants. Austral. J. Agr. Res. 20:291-300.

Lowell, C.A.,P.T. Tomlinson, and K.E. Koch. 1989. Sucrose-metabolizing enzymes in transport tissues and adjacent sink structures in developing citrus fruit. Plant Physiol. 90:1394-1402.

McCutchan, H. and K.A. Shackel. 1992. Stem-water potential as a sensitive indicator of water stress in prune trees (Prunus domestica L. cv. French). J. Amer. Soc. Hort. Sci. 117:607-611.

Menocal-Barberena, O.A. 1999. Citrus fibrous root distribution as affected by rootstock and irrigation rates of reclaimed water. MS Thesis, Dept. Hort. Sci., Univ. of Fla., Gainesville.

Meyer, R.F. and J.S. Boyer. 1981. Osmoregulation, solute distribution, and growth in soybean seedlings having low water potentials. Planta 1151:482-489.

Miller, W.M. 1990. Internal quality attributes of the Florida Valencia orange and their relationship to fruit density measurements. Appl. Eng. Agr. 6:461-464. 
Reitz, H.J. and T.W. Embleton. 1986. Production practices that influence fresh fruit quality, p. 49-78. In: W.J. Wardowski, S. Nagy, and W. Grierson (eds.). Fresh fruit citrus. AVI, Westport, Conn.

SAS Institute. 1996. SAS user's guide: Statistics, Version 5 ed. SAS Inst., Cary, N.C.

Sawamura, M., M. Nakashima, and Y. Osajima. 1975. Studies on translocation of ${ }^{14} \mathrm{C}$-labeled compounds from leaves to fruit in Satsuma mandarin (in Japanese with English summary). J. Agr. Chem. Soc. Jpn. 49:603-607.

Scholander, P.F., H.T. Hammel, E.D. Bradstreet, and E.A. Hemmingsen. 1965. Sap pressure in vascular plants. Science 148:339-346.

Shackel, K.A., H. Ahmadi, W. Biasi, R. Buchner, D. Goldhamer, S. Gurusinghe, J. Hasey, D. Kester, B. Krueger, B. Lampinen, G. McGourty, W. Micke, E. Mitcham, B. Olson, K. Pelletrau, H. Philips, D. Ramos, L. Schwankl, S. Sibbett, R. Snyder, S. Southwick, M. Stevenson, M. Thorpe, S. Weinbaum, and J. Yeager. 1997. Plant water status as an index of irrigation need in deciduous fruit trees. HortTechnology 7:23-30.

Sites, J.W., H.J. Reitz, and E.J. Deszyck. 1951. Some results of irrigation research with Florida citrus. Proc. Fla. State Hort. Soc. 64:71-79.

Sodek, F. III., V.W. Carlisle, M.E. Collins, L.C. Hammond, and W.G. Harris. 1990. Characterization data for selected Florida soils. Inst. Food Agr. Sci., Univ. of Fla., Gainesville, Soil Sci. Res. Rpt. No. 90-1.

Song, K.J., E. Echeverria, and H.S. Lee. 1998. Distribution of sugars and related enzymes in the stem and blossom halves of 'Valencia' oranges. J. Amer. Soc. Hort. Sci. 123:416-429.
Sugai, H. and H. Torikata. 1976. Effects of soil moisture content in early autumn on growth and juice constituents of Satsuma mandarin fruit (in Japanese with English summary). J. Jpn. Soc. Hort. Sci. 44:330-337.

Syvertsen, J.P. and L.G. Albrigo. 1980. Some effects of grapefruit tree canopy position on microclimate, water relations, fruit yield, and juice quality. J. Amer. Soc. Hort. Sci. 105:454-459.

Syvertsen, J.P. and J.H. Graham. 1985. Hydraulic conductivity of roots, mineral nutrition, and leaf gas exchange of citrus rootstocks. J. Amer. Soc. Hort. Sci. 110:865-869.

Vasconcellos, L.A.B.C. and W.S. Castle. 1994. Trunk xylem anatomy of mature healthy and blighted grapefruit trees on several rootstocks. J. Amer. Soc. Hort. Sci. 119:185-194.

Wutscher, H.K. 1979. Citrus rootstocks. Hort. Rev. 1:239-269.

Wutscher, H.K. 1988. Rootstock effects on fruit quality, p. 24-34. In: J.J. Ferguson and W.F. Wardowski (eds.). Factors affecting fruit quality. Citrus Short Course Proc., Fruit Crops Dept., Univ. of Fla., Gainesville.

Yakushiji, H., K. Morinaga, and H. Nonami. 1998. Sugar accumulation and partitioning in Satsuma mandarin tree tissues and fruit in response to drought stress. J. Amer. Soc. Hort. Sci. 123:719-726.

Yakushiji, H., H. Nonami, T. Fukuyama, S. Ono, N. Takagi, and Y. Hashimoto. 1996. Sugar accumulation enhanced by osmoregulation in Satsuma mandarin fruit. J. Amer. Soc. Hort. Sci. 121:466-472. 